\title{
Fertility estimates in the Tunisian all- acrocentric and Robertsonian populations of the house mouse and their chromosomal hybrids
}

\author{
KHALED SAID*, ALI SAAD $\dagger$, JEAN-CHRISTOPHE AUFFRAY $\ddagger \&$ \\ JANICE BRITTON-DAVIDIAN \\ *Faculté de Pharmacie de Monastir, Service de Biologie et Physiologie Animales, 5000 Monastir; $\dagger$ Laboratoire de \\ Cytogénétique et de Biologie de la Reproduction, CHU, 4000 Sousse, Tunisia; and $\ddagger$ Laboratoire Génétique et \\ Environnement, Institut des Sciences de I'Evolution (URA 327 CNRS), Université Montpellier II, Place Eugéne Bataillon, \\ 34095 Montpellier Cedex 5, France
}

The reproductive features of wild all-acrocentric and $2 n=22$ Robertsonian (Rb) house mice $(M$. $m$. domesticus) from Tunisia were studied. The aim was to examine the possibility of a reproductive selective advantage associated with chromosomal change as well as to measure the effect of heterozygosity for a large number of $\mathrm{Rb}$ fusions on the fertility of hybrids. Results showed that litter sizes were significantly smaller in Rb than in all-acrocentric mice. This difference, which may represent a favourable demographic strategy related to the habitat segregation observed in the Tunisian mice, needs to be studied further. The $\mathrm{F}_{1}$ hybrids between the two chromosomal races showed a significantly reduced reproductive success and litter size (respectively, 53 per cent and 60 per cent less than either parental race). Analysis of the testicular histology of $F_{1}$ and backcross males showed in some cases a breakdown of spermatogenesis. The degree of this disturbance was not related to the level of chromosomal heterozygosity suggesting that genetic incompatibilities between the two genomes might be involved. The strong reduction in fertility measured in these hybrids represents a reproductive isolating mechanism effectively reducing gene flow between the all-acrocentric and $22 \mathrm{Rb}$ mice populations of Tunisia.

Keywords: chromosomal evolution, chromosomal heterozygosity, hybrid sterility, Rb fusion, spermatogenesis, wild house mice.

\section{Introduction}

Chromosomal divergence has proceeded in the house mouse (Mus musculus domesticus) by the fixation and accumulation of Robertsonian ( $\mathrm{Rb}$ ) translocations formed by the centric fusion of acrocentric chromosomes (Capanna, 1982). In Monastir (Tunisia) the Rb populations of house mice are fixed for nine pairs of $\mathrm{Rb}$ fusions $(2 n=22)$, the combination of which is not known to occur elsewhere (Said et al., 1986, 1991). This $\mathrm{Rb}$ race exhibits certain specific traits when compared with European $\mathrm{Rb}$ mice. In the Monastir area, the Tunisian $\mathrm{Rb}$ populations occupy exclusively urban centres whereas all-acrocentric populations occur in

\footnotetext{
${ }^{*}$ Correspondence.
}

small rural villages. At the border between these two types of habitat, chromosomally polymorphic mice can be found, although in some cases where the transition from one karyotype to the other takes place in less than $1 \mathrm{~km}$, no intermediate karyomorphs were detected. Allozymic studies have shown that the $\mathrm{Rb}$ and allacrocentric mice could be differentiated. The genic divergence is in fact the largest measured so far between all-acrocentric and $\mathrm{Rb}$ populations and argues in favour of a chromosomal barrier to gene flow through a severe decrease in fertility. The $\mathrm{Rb}$ populations from Tunisia seem to represent in fact one of the clearest examples of chromosomally-mediated reproductive isolation (White, 1968).

The effects on fertility of chromosomal structural heterozygosity in house mice have been extensively 
investigated, but most studies have focused on hybrids between mice carrying different $\mathrm{Rb}$ fusions (Gropp et al., 1982; Redi et al., 1985; Redi \& Capanna, 1988). Additional papers dealing with hybrids between $\mathrm{Rb}$ and all-acrocentric mice have shown a decrease in fertility mainly due to the production of aneuploid gametes (Cattanach \& Moseley, 1973; Redi \& Capanna, 1978), the extent of which is related to the number of heterozygous fusions (Winking \& Gropp, 1976; Gropp \& Winking, 1981). However, most of these estimates were obtained by crossing $\mathrm{Rb}$ mice with all-acrocentric laboratory strains and do not accurately depict the situation occurring in the wild. Results for wild hybrids indicate that fertility is slightly if at all affected in the case of heterozygotes for one to three fusions (see Viroux \& Bauchau, 1992; Wallace et al., 1992). In this study, we attempt to measure hybrid sterility in the progeny of Tunisian Rb mice and neighbouring all-acrocentric wild mice which differ by nine pairs of $\mathrm{Rb}$ fusions.

The fixation and spread of chromosomal re-arrangements have been extensively reviewed in a number of theoretical investigations (see review in Sites \& Mortiz, 1987; Barton \& Rouhani, 1991; Spirito et al., 1991; Spirito, 1992; Michalakis \& Olivieri, 1993). Among the factors favouring chromosomal change, meiotic drive, genetic drift, inbreeding and the selective advantage of the chromosomally variant individuals or populations have been considered as the most relevant. Although the first three factors have been investigated (see Britton-Davidian et al., 1989; Viroux \& Bauchau, 1992; Wallace et al., 1992) and do not appear to operate in the $\mathrm{Rb}$ differentiation of house mice, the search for a selective advantage has received little attention. In this work, we compare one component of the reproductive fitness by measuring progeny size in wild $\mathrm{Rb}$ and all-acrocentric mice.

\section{Materials and methods}

\section{The crosses}

The mice used in the fertility analyses were livetrapped in Monastir City $(2 n=22)$, and Mahdia, Sfax, Jebiniana, Sbeitla and Sidi-Bouzid $(2 n=40)$. The distance between Monastir and the $2 n=40$ localities varied between $36 \mathrm{~km}$ at the least and $250 \mathrm{~km}$ at the most. Mice were kept under standard laboratory conditions with $12 \mathrm{~h}$ of daylight and at $20^{\circ} \mathrm{C}$ temperature. Five series of crosses were established: (i) $2 n=22 \times 2 n=22$ : seven pairs; (ii) $2 n=40 \times 2 n=40$ : five pairs; (iii) $2 n=40$ ( 4 females, 4 males) $\times 2 n=22$ (4 f, $4 \mathrm{~m})$ : eight pairs; (iv) $\mathrm{F}_{1}(2 n=31) \quad(4 \mathrm{f}$, $3 \mathrm{~m}) \times 2 n=40(3 \mathrm{f}, 4 \mathrm{~m})$ : seven pairs; (v) $\mathrm{F}_{1}(2 n=31)$ $(4 \mathrm{f}, 4 \mathrm{~m}) \times 2 n=22(4 \mathrm{f}, 4 \mathrm{~m})$ : eight pairs.
The number of litters as well as the number of pups per litter were recorded for over a year. Two $F_{1} s$ and most of the progeny from the backcrosses were karyotyped following the air drying method for bone marrow cells after yeast stimulation (Lee \& Elder, 1980). Standard Giemsa-stained slides allowed to determine their diploid number with which the degree of heterozygosity for $\mathrm{Rb}$ fusions could be estimated.

\section{Histological preparation of testes}

Testicular histological preparations were made for 28 individuals, among which were two $F_{1} s$ and 17 of their progeny. Testes were soaked in Bouin's fixative and embedded in paraffin from which $5 \mu \mathrm{m}$ thick histological sections were prepared. For each individual, the sections from one of the testes were stained with haematoxylin and eosin and viewed under the light microscope. About 100 transverse cross-sections of seminiferous tubules were examined per testis to determine the testicular histopathology interpretation score (TMI) classically used in the quantification of human male sterility. The TMI score is a semi-quantitative method which attributes a value to the biopsy according to the state of the seminiferous tubules, the peritubular membranes and the interstitial space. The TMI score used in the present study (Table 1) was modified following Lecornu et al. (1984). Since the peritubular membrane and the interstitial space were not pathologically affected (score of 0 in all individuals examined), they were omitted from the scoring.

\section{Results}

\section{Reproductive success and progeny size}

The reproductive success is here expressed as the effective production of progeny by a pair of mice and was measured in all series of crosses (Table 2). The results show that 100 per cent of the intraracial crosses yielded progeny as compared with 87.5 per cent of the interracial ones. Backcrosses showed the lowest reproductive success rate, since only slightly more than half of the pairs (53 per cent) yielded progeny. Statistical comparisons of these results by Fisher's exact test showed that backcrosses had a significantly lower reproductive success than did the inter- and intraracial ones (respectively $\alpha=1.81 \times 10^{-13}$ and $\alpha=3.45 \times 10^{-5}$ ), whereas the differences between the latter two crosses were not significant $(\alpha=0.4$ ).

The analysis of the mean litter size (Table 2) showed that within the intraracial crosses, the all-acrocentric yielded a higher mean litter size than the Rb crosses, while the lowest mean progeny size was found in the backcrosses. The two-level nested anOvas per- 
Table 1 Modified TMI score following Lecornu et al.(1974) yielding a maximum score of 7

\begin{tabular}{|c|c|c|c|}
\hline \multicolumn{2}{|l|}{ Testicular parameters } & \multicolumn{2}{|l|}{ TMI score } \\
\hline $\begin{array}{l}\text { DT } \\
\text { Diameter of tubes }\end{array}$ & $\begin{array}{l}0 \text { Normal in more than } 50 \% \\
\text { of tubes }\end{array}$ & $\begin{array}{l}1 \text { Reduced in } 50-80 \% \\
\text { of tubes }\end{array}$ & $\begin{array}{l}2 \text { Reduced in more than } \\
80 \% \text { of tubes }\end{array}$ \\
\hline $\begin{array}{l}\text { DF } \\
\text { Cell differentiation }\end{array}$ & $\begin{array}{l}0 \text { Sperm in more than } 50 \% \\
\text { of tubes }\end{array}$ & $\begin{array}{l}1 \text { Sperm in less than } 50 \% \\
\text { of tubes }\end{array}$ & 2 No sperm \\
\hline $\begin{array}{l}\mathrm{N} \\
\text { Necrobiosis }\end{array}$ & $\begin{array}{l}0 \text { Absent or present in few } \\
\text { tubes }\end{array}$ & 1 Present in many tubes & \\
\hline $\begin{array}{l}\text { E } \\
\text { Exfoliation }\end{array}$ & $\begin{array}{l}0 \text { Absent or mild in few } \\
\text { tubes }\end{array}$ & 1 Mild in many tubes & 2 Frequent in many tubes \\
\hline
\end{tabular}

Table 2 Reproductive success and mean litter size for the different types of crosses. $\mathrm{R}=$ number of pairs having produced progeny; $\mathrm{NR}=$ number of pairs without progeny.

\begin{tabular}{lrlll}
\hline Cross & & & & $\begin{array}{l}\text { Mean litter } \\
\text { size }\end{array}$ \\
\hline Intraracial & R & NR & Litters & \\
$\quad 22 \times 22$ & 7 & 0 & 24 & 3.6 \\
$40 \times 40$ & 5 & 0 & 15 & 6.0 \\
$\quad$ Total & 12 & 0 & 39 & 4.5 \\
Interracial & & & & \\
M40 $\times$ F22 & 3 & $1 *$ & 6 & 3.7 \\
M22 $\times$ F40 & 4 & 0 & 8 & 5.4 \\
Total & 7 & 1 & 14 & 4.6 \\
Backcross & & & & \\
M31 $\times$ F22 & 3 & 1 & 18 & 1.8 \\
M22 $\times$ F31 & 1 & 3 & 4 & 1.7 \\
M31 $\times$ F40 & 1 & 2 & 3 & 2.0 \\
M40 $\times$ F31 & 3 & 1 & 5 & 1.4 \\
Total & 8 & 7 & 30 & 1.8 \\
\hline
\end{tabular}

*These individuals come from localities $36 \mathrm{~km}$ apart.

formed on these results (Table 3) show that the difference in mean litter size between all-acrocentric and $\mathrm{Rb}$ mice was significant. Likewise, backcrosses, whether $F_{1}$ males or females, had a significantly smaller progeny size than any other type of cross. On the other hand, the mean litter size observed in the interracial crosses was not significantly different from that of the intraracial ones. However, when data were compared between sexes by pooling all but backcrosses, significant differences in litter size are observed between females but not males, with the $22 \mathrm{Rb}$ females producing less progeny per litter regardless of the mate's karyotype.

\section{Testicular histology}

Histological testicular sections of a $22 \mathrm{Rb}$, an all-acrocentric and two heterozygous mice are provided in Fig. 1 and the results of the TMI score in Table 4. The seminiferous tubules of the wild $2 n=22$ and $2 n=40$ Tunisian mice show that the histoarchitectural disposition of the germ cells is normal yielding a TMI score of 0 . In the chromosomally heterozygous individuals, the TMI scores were very variable reaching in some cases high values denoting a total arrest of spermatogenesis. Alterations were evident in the seminiferous tubules in which the tubular diameter, cellular differentiation and density were reduced. Exfoliation of the different cell lines was observed as well as signs of necrobiosis within the seminiferous tubules.

To test the relationship between chromosomal heterozygosity and sterility, all individuals were assigned a fertility index $(\mathrm{S}=$ sterile, $\mathrm{SF}=$ subfertile and $\mathrm{F}=$ fertile) derived from the cellular differentiation score (Table 4) corresponding respectively to the absence $($ d.f. $=2)$, intermediate $($ d.f. $=1)$ or normal $($ d.f. $=0)$ amount of sperm in the backcrosses (Fig. 2). Results indicated that neither the TMI score nor the fertility value were related to the number of fusions in a heterozygote state (Spearman coefficient of correlation: $\mathrm{Ms}=0.18, P=0.46$ and $\mathrm{Ms}=0.15, P=0.53$, respectively) and that the segregation of fusions in the progeny was apparently random $\left(\chi^{2}=0 ; 15\right.$, d.f. $=8$, $\mathrm{P}>>0.05)$. That the disturbance of the spermatogenetic process may be independent of chromosomal heterozygosity per se is suggested by a $2 n=31$ individual which was scored as fertile and the SF value found in a homozygous 22-chromosome mouse.

The reproductive success rate and testicular histology score gave congruent results in the two $F_{1}$ males analysed by both methods. The first one yielded no progeny and was classified as sterile (S) for the fertility index, whereas the second one which had produced 
progeny did not show any obvious disturbance of the testicular histology $(\mathrm{F})$. However, the mean litter size sired by this individual was reduced (2.0) compared with that for the within or between race data (Table 2 ).

\section{Discussion}

\section{Comparison of litter sizes}

Significant statistical differences in litter size were established between the two chromosomal races. A priori,

Table 3 Two-level nested ANOVA statistics on litter size among types of crosses between chromosomal groups. The comparisons involving only one sex include both inter- and intraracial crosses (see text for explanation)

\begin{tabular}{|c|c|c|c|c|c|c|}
\hline Crosses & Source of variation & Sum of square & d.f. & Mean of square & $F$ & $P$ \\
\hline All & $\begin{array}{l}\text { Among types of crosses } \\
\text { Among pairs within types } \\
\text { Residual } \\
\text { Total }\end{array}$ & $\begin{array}{r}213.2 \\
83.1 \\
76.2 \\
372.5\end{array}$ & $\begin{array}{r}7 \\
19 \\
56 \\
82\end{array}$ & $\begin{array}{r}30.5 \\
4.4 \\
1.4\end{array}$ & $\begin{array}{l}6.96 \\
3.21\end{array}$ & $\begin{array}{l}* * \\
* *\end{array}$ \\
\hline $\begin{array}{l}22 \times 22 \\
\text { vs. } \\
40 \times 40\end{array}$ & $\begin{array}{l}\text { Among types of crosses } \\
\text { Among pairs within types } \\
\text { Residual } \\
\text { Total }\end{array}$ & $\begin{array}{r}52.1 \\
67.0 \\
50.7 \\
169.7\end{array}$ & $\begin{array}{r}1 \\
10 \\
27 \\
38\end{array}$ & $\begin{array}{r}52.1 \\
6.7 \\
1.9\end{array}$ & $\begin{array}{l}7.78 \\
3.57\end{array}$ & $\begin{array}{l}* \\
* *\end{array}$ \\
\hline $\begin{array}{l}22 \times 22 \\
\text { vs. } \\
\text { interracial }\end{array}$ & $\begin{array}{l}\text { Among types of crosses } \\
\text { Among pairs within types } \\
\text { Residual } \\
\text { Total }\end{array}$ & $\begin{array}{r}9.2 \\
40.3 \\
48.5 \\
98.0\end{array}$ & $\begin{array}{r}1 \\
12 \\
24 \\
37\end{array}$ & $\begin{array}{l}9.2 \\
3.4 \\
2.0\end{array}$ & $\begin{array}{l}2.72 \\
1.66\end{array}$ & - \\
\hline $\begin{array}{l}22 \times 22 \\
\text { vs. } \\
\text { backcross }\end{array}$ & $\begin{array}{l}\text { Among types of crosses } \\
\text { Among pairs within types } \\
\text { Residual } \\
\text { Total }\end{array}$ & $\begin{array}{r}46.0 \\
26.0 \\
53.0 \\
125.0\end{array}$ & $\begin{array}{r}1 \\
13 \\
39 \\
53\end{array}$ & $\begin{array}{r}46.0 \\
2.0 \\
1.4\end{array}$ & $\begin{array}{r}23.04 \\
1.47\end{array}$ & ** \\
\hline $\begin{array}{l}40 \times 40 \\
\text { vs. } \\
\text { interracial }\end{array}$ & $\begin{array}{l}\text { Among types of crosses } \\
\text { Among pairs within types } \\
\text { Residual } \\
\text { Total }\end{array}$ & $\begin{array}{r}13.3 \\
68.0 \\
23.2 \\
104.6\end{array}$ & $\begin{array}{r}1 \\
10 \\
17 \\
28\end{array}$ & $\begin{array}{r}13.3 \\
6.8 \\
1.4\end{array}$ & $\begin{array}{l}1.96 \\
4.99\end{array}$ & - \\
\hline $\begin{array}{l}40 \times 40 \\
\text { vs. } \\
\text { backcross }\end{array}$ & $\begin{array}{l}\text { Among types of crosses } \\
\text { Among pairs within types } \\
\text { Residual } \\
\text { Total }\end{array}$ & $\begin{array}{r}113.3 \\
24.0 \\
126.9 \\
264.3\end{array}$ & $\begin{array}{r}1 \\
11 \\
32 \\
44\end{array}$ & $\begin{array}{r}113.3 \\
2.2 \\
4.0\end{array}$ & $\begin{array}{r}51.88 \\
0.55\end{array}$ & $\begin{array}{l}* * \\
-\end{array}$ \\
\hline $\begin{array}{l}\text { Interracial } \\
\text { vs. } \\
\text { backcross }\end{array}$ & $\begin{array}{l}\text { Among types of crosses } \\
\text { Among pairs within types } \\
\text { Residual } \\
\text { Total }\end{array}$ & $\begin{array}{r}79.0 \\
27.1 \\
25.5 \\
131.5\end{array}$ & $\begin{array}{r}1 \\
13 \\
29 \\
43\end{array}$ & $\begin{array}{r}79.0 \\
2.1 \\
0.9\end{array}$ & $\begin{array}{r}37.93 \\
2.37\end{array}$ & $\begin{array}{l}* * \\
*\end{array}$ \\
\hline $\begin{array}{l}\text { Female } 22 \\
\text { vs. } \\
\text { Female } 40\end{array}$ & $\begin{array}{l}\text { Among types of crosses } \\
\text { Among pairs within types } \\
\text { Residual } \\
\text { Total }\end{array}$ & $\begin{array}{r}60.1 \\
79.7 \\
61.2 \\
201.0\end{array}$ & $\begin{array}{r}1 \\
17 \\
34 \\
52\end{array}$ & $\begin{array}{r}60.1 \\
4.7 \\
1.8\end{array}$ & $\begin{array}{r}12.82 \\
2.61\end{array}$ & $\begin{array}{l}* * \\
*\end{array}$ \\
\hline $\begin{array}{l}\text { Male } 22 \\
\text { vs. } \\
\text { Male } 40\end{array}$ & $\begin{array}{l}\text { Among types of crosses } \\
\text { Among pairs within types } \\
\text { Residual } \\
\text { Total }\end{array}$ & $\begin{array}{r}20.5 \\
119.4 \\
61.2 \\
201.0\end{array}$ & $\begin{array}{r}1 \\
17 \\
34 \\
52\end{array}$ & $\begin{array}{c}20.5 \\
7.0 \\
1.79\end{array}$ & $\begin{array}{l}2.92 \\
3.90\end{array}$ & - \\
\hline $\begin{array}{l}\text { Female } 31 \\
\text { vs. } \\
\text { Male } 31\end{array}$ & $\begin{array}{l}\text { Among types of crosses } \\
\text { Among pairs within types } \\
\text { Residual } \\
\text { Total }\end{array}$ & $\begin{array}{r}0.2 \\
6.1 \\
15.0 \\
21.4\end{array}$ & $\begin{array}{r}1 \\
6 \\
22 \\
29\end{array}$ & $\begin{array}{l}0.2 \\
1.0 \\
0.7\end{array}$ & $\begin{array}{l}0.21 \\
1.50\end{array}$ & - \\
\hline
\end{tabular}

${ }^{*} P<0.05 ; * * P<0.01$. 

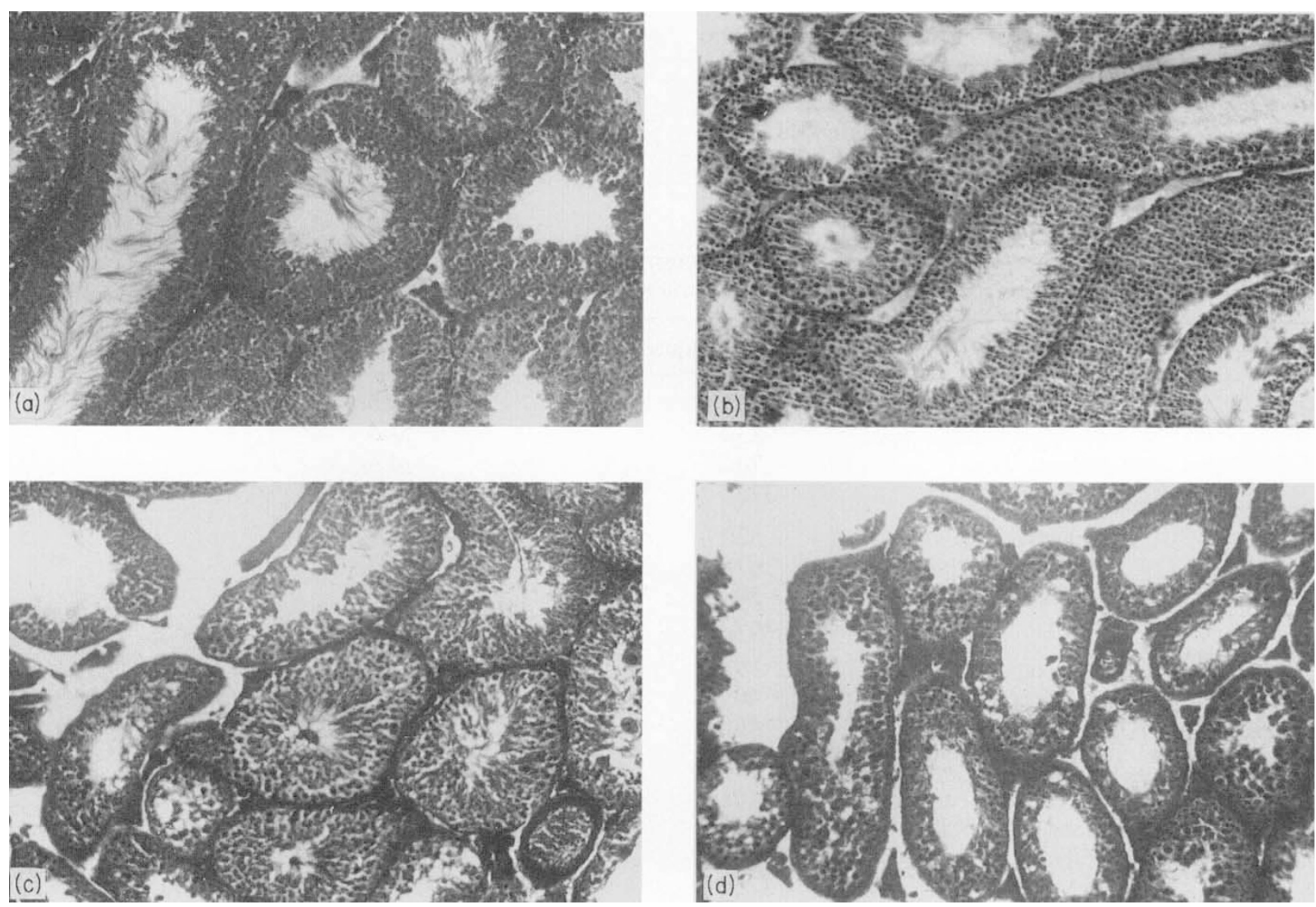

Fig. 1 Histological sections of testes. (a) and (b) Fertile parental males with a TMI score $=0,(a) 2 n=40(\times 150)$ and (b) $2 n=22$ $(\times 125)$. (c) Sterile $2 n=31$ backcross male $(T M I=2)$; note absence of spermatozoa in tubule lumen $(\times 150)$. (d) Subfertile $2 n=25$ backcross male $(\mathrm{TMI}=2)$ showing extensive exfoliation $(\times 150)$.

a smaller mean litter size in $\mathrm{Rb}$ mice would not be considered as a selectively advantageous character allowing the rapid spread of fusions within populations. However, this observation denotes a difference in life history traits which may be related to the habitat segregation shown by the two races since the Tunisian $22 \mathrm{Rb}$ mice are found exclusively in urban centres, whereas the all-acrocentric populations are present in rural villages. The hypothesis of a difference in demographic strategies needs to be validated by the analysis of reproductive traits (frequency, cycle, etc.) and of survival rates in each habitat.

\section{Fertility of hybrids}

The results from the crosses indicate that the $2 n=31$ heterozygotes show a significantly reduced reproductive success rate and litter size compared with those of crosses between chromosomally homozygous individuals. This is in agreement with previous studies on the fertility of $\mathrm{Rb}$ chromosomal hybrids (Winking \&
Gropp, 1976; Gropp \& Winking, 1981; Gropp et al., 1982). These authors have shown that the formation of trivalents in these hybrids leads to the production of viable aneuploid gametes and postzygotic elimination of embryos. Under this assumption, the decrease in fertility is attributed to malsegregation due to orientation of trivalents, univalence or inadequate pairing (Moses et al., 1979; Elder \& Pathak, 1980; Redi \& Capanna, 1988; Haaf et al., 1989; Mahadevaiah et al., 1990; Wallace \& Searle, 1990). These authors indicate additionally that the non-disjunction rates are higher in females than in males, vary with the type of fusion and are related to the number of fusions in a heterozygous state (Winking \& Gropp, 1976; Gropp \& Winking, 1981). However, very few of these reports involve wild heterozygotes for many Rb trivalents. Redi \& Capanna (1978) estimated a correct disjunction rate of 38 per cent for male hybrids between wild all-acrocentric and $2 n=22 \mathrm{CD}$ Italian mice (nine trivalents) which is remarkably similar to the decrease in litter size measured in the $F_{1}$ hybrid Tunisian mice. Similarly, 
Table 4 Testicular histopathology and TMI score for all individuals analysed. $2 n=$ diploid number; DT $=$ diameter of tubules; $\mathrm{DF}=$ cellular differentiation; $\mathrm{N}=$ necrobiosis; $\mathrm{E}=$ exfoliation. $K=$ number of fusions in a heterozygous state

\begin{tabular}{|c|c|c|c|c|c|c|c|}
\hline $\begin{array}{l}\text { Type of } \\
\text { cross }\end{array}$ & $2 n$ & DT & DF & $\mathrm{N}$ & $\mathrm{E}$ & $\begin{array}{l}\text { TMI } \\
\text { score }\end{array}$ & $K$ \\
\hline \multirow[t]{9}{*}{ Parents } & 40 & 0 & 0 & 0 & 0 & 0 & 0 \\
\hline & 40 & 0 & 0 & 0 & 0 & 0 & 0 \\
\hline & 40 & 0 & 0 & 0 & 0 & 0 & 0 \\
\hline & 22 & 0 & 0 & 0 & 0 & 0 & 0 \\
\hline & 22 & 0 & 0 & 0 & 0 & 0 & 0 \\
\hline & 22 & 0 & 0 & 0 & 0 & 0 & 0 \\
\hline & 22 & 0 & 0 & 0 & 0 & 0 & 0 \\
\hline & 22 & 0 & 0 & 0 & 0 & 0 & 0 \\
\hline & 22 & 0 & 0 & 0 & 0 & 0 & 0 \\
\hline \multirow[t]{2}{*}{$F_{1}$} & 31 & 0 & 2 & 0 & 0 & 2 & 9 \\
\hline & 31 & 0 & 0 & 0 & 0 & 0 & 9 \\
\hline \multirow[t]{17}{*}{ Backcross } & 22 & 0 & 1 & 0 & 1 & 2 & 0 \\
\hline & 24 & 0 & 0 & 0 & 0 & 0 & 2 \\
\hline & 24 & 0 & 1 & 0 & 1 & 2 & 2 \\
\hline & 25 & 0 & 1 & 0 & 1 & 2 & 3 \\
\hline & 25 & 0 & 2 & 0 & 1 & 3 & 3 \\
\hline & 25 & 0 & 2 & 1 & 2 & 5 & 3 \\
\hline & 26 & 0 & 1 & 0 & 1 & 2 & 4 \\
\hline & 26 & 0 & 2 & 0 & 1 & 3 & 4 \\
\hline & 26 & 0 & 1 & 0 & 1 & 2 & 4 \\
\hline & 27 & 0 & 0 & 0 & 0 & 0 & 5 \\
\hline & 27 & 0 & 0 & 0 & 0 & 0 & 5 \\
\hline & 27 & 0 & 2 & 1 & 1 & 4 & 5 \\
\hline & 27 & 0 & 2 & 0 & 2 & 4 & 5 \\
\hline & 28 & 1 & 1 & 0 & 2 & 4 & 6 \\
\hline & 29 & 0 & 1 & 0 & 0 & 1 & 7 \\
\hline & 31 & 0 & 0 & 0 & 0 & 0 & 9 \\
\hline & 34 & 0 & 1 & 0 & 2 & 3 & 6 \\
\hline
\end{tabular}

Garagna et al. (1990) observed a reduction in the number of oocytes in wild female heterozygotes with seven trivalents.

However, the data from the Tunisian chromosomal hybrids further indicate that a disturbance of the gametogenetic process unrelated to non-disjunction is observed in the male heterozygotes. It is apparent then, that two processes are operating in the overall decrease in fertility: (i) aneuploidy due to non-disjunction events is involved in the decrease in litter size as suggested by that of the $F_{1}$ male which showed no disturbance in testicular histology. Non-disjunction rates may be positively related to the extent of chromosomal heterozygosity but were not directly measured; and (ii) disturbances of the spermatogenetic process are

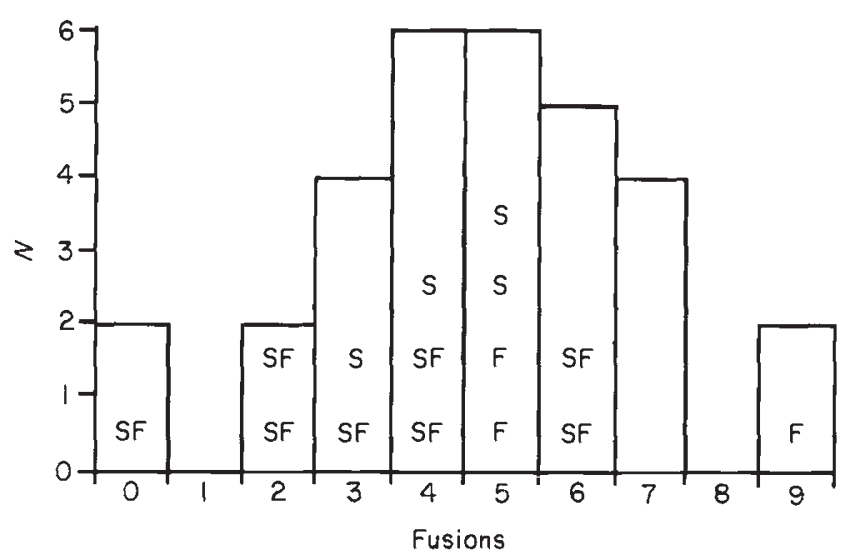

Fig. 2 Distribution of fertility score and number of $\mathrm{Rb}$ fusions in a heterozygous state $(0-9)$ in the pooled backcross progeny. Each male is represented by its fertility score $(\mathrm{S}=$ sterile, $\mathrm{SF}=$ subfertile, $\mathrm{F}=$ fertile $)$ and each female by a blank.

present leading to complete sterility in some cases. Furthermore, no relation was observed between the number of fusions in a heterozygous state and the presence or extent of the spermatogenic impairment which seems more likely to result from genic differences between the parental chromosomal races such as has been observed previously (Cattanach \& Moseley, 1973; Winking et al., 1988). The genetic incompatibilities between the two genomes would then reinforce the non-disjunctive effect of the fusion further lowering the overall fertility scores.

The two reproductive features measured in this study show that $\mathrm{Rb}$ chromosomal heterozygosity for nine fusions leads to a severe impairment of fertility by failure to reproduce and/or severe reduction in litter size. In addition to non-disjunction of chromosomes leading to aneuploidy, the reduction in reproductive fitness of male hybrids is related to disturbances of the spermatogenetic process acting through or due to genomic interactions but not to chromosomal heterozygosity per se. These factors contribute to the reproductive isolation between the $22 \mathrm{Rb}$ and the all-acrocentric house mouse populations and to maintain the genetic differentiation observed in these two chromosomal races. The low reproductive rates of $F_{1}$ individuals also explains the spatially and temporally limited distribution of hybrid populations. The difference in mean litter size between the all-acrocentric and $22 \mathrm{Rb}$ mice represents an original observation, the adaptive value of which, if any, needs to be ascertained.

\section{Acknowledgements}

We wish to thank J. Catalan for her excellent technical assistance and Dr A. El Gaied for her interest in this 
research. This study was supported by grants to the Faculté de Pharmacie de Monastir, to the CHU in Sousse and to the Université Montpellier II and CNRS URA327 in Montpellier. Travel expenses were financed by OMS and CIES grants to K. Saïd as well as by a DRST-CNRS cooperation program. This is contribution No. 93-037 of the Institut des Sciences de l'Evolution (URA 327 CNRS).

\section{References}

BARTON, N. H. AND ROUHANI, s. 1991. The probability of fixation of a new karyotype in a continuous population. Evolution, 45, 499-517.

BRITTON-DAVIDIAN, J., NADEAU, J. H., CROSET, H. AND THALER, L. 1989. Genic differentiation and origin of Robertsonian populations of the house mouse (Mus musculus domesticus L.). Genet. Res., 53, 29-44.

CAPANNA, E. 1982. Robertsonian numerical variation in animal speciation: Mus musculus, an emblematic model. In: Liss, A. R. (ed.) Mechanisms of Speciation, pp. 155-177.

CATtanach, B. M. AND MOSEley, H. 1973. Nondisjunction and reduced fertility caused by the tobacco mouse metacentric chromosomes. Cytogenet. Cell Genet, 12, 264-287.

ELDER, F. F. B. AND PATHAK, S. 1980. Light microscopic observations on the behavior of silver-stained trivalents in pachytene cells of Sigmodon fulvidenter (Rodentia, Muridae) heterozygous for centric fusions. Cytogenet. Cell Genet., 27, 31-38.

GARAGNA, S., REDI, C. A., ZUCCOTTI, M., BRITTON-DAVIDIAN, J. AND WINKING, H. 1990. Kinetics of oogenesis in mice heterozygous for Robertsonian translocations. Differentiation, 42, 167-171.

GROPP, A. AND WINKING, H. 1981. Robertsonian translocations: cytology, meiosis, segregation pattern and biological consequences of heterozygosity. Symp. Zool. Soc. London, 47, 141-181.

GROPP, A., WINKING, H. AND REDI, C. 1982. Consequences of Robertsonian heterozygosity: segregational impairment of fertility versus male-limited sterility. In: Crosignani, P. G. and Rubin, S. (eds) Genetic Control of Gamete Production and Function, Academic Press, New York, pp. 115-134.

HAAF, T., WINKING, H. AND SCHMID, M. 1989. Immunocytogenetics. III. Analysis of trivalent and multivalent configurations in mouse pachytene spermatocytes by human antibodies to synaptonemal complexes and kinetochores. Cytogenet. Cell Genet., 50, 14-22.

LECORNU, F., LEBOURBOUAC'H, P., MiLAN, J. J. AND COGNAT, M. 1984. Que penser du T.M.I.? Score d'interprétation de l'histopathologie testiculaire. In: Arvis, G. and Dadoune, J.-P. (eds) La Biopsie Testiculaire, SIMEP, Lyon-Villeurbanne, pp. 34-39.

LEE, M. R. AND ELDER, F. F. B. 1980. Yeast stimulation of bone marrow mitosis for cytogenetic investigation. Cytogenet. Cell Genet., 26, 36-40.

MAHADEVAiAH, S. K., SETTERFIELD, L. A. AND MITTWOCH, U. 1990. Pachytene pairing and sperm counts in mice with single
Robertsonian translocations and monobrachial compounds. Cytogenet. Cell Genet., 53, 26-31.

MICHALAKIS, Y. AND OLIVIERI, I. 1993. The influence of local extinctions on the probability and time to fixation of chromosomal rearrangements. J. Evol. Biol., 6, 153-170.

moses, M. J., KARATSIS, P. A. AND hamilton, E. A. 1979. Synaptonemal complex analysis of heteromorphic trivalents in Lemur hybrids. Chromosoma, 70, 141-160.

REDI, C. A. AND CAPANNA, E. 1978. DNA-content variation in mouse spermatozoa arising from irregular meiotic segregation. Boll. Zool., 45, 315-322.

REDI, C. A. AND CAPANNA, E. 1988. Robertsonian heterozygotes in the house mouse and the fate of their germ cells. In: Riss, A. R. (ed.) The Cytogenetics of Mammalian Rearrangements, pp. 315-359.

REDI, C. A., GARAgnA, S., HilsCHER, B. AND Winking, H. 1985. The effects of some Robertsonian chromosome combinations on the seminiferous epithelium of the mouse. J. Embryol. exp. Morph., 85, 1-19.

SAID, K., JACQUART, T., MONTGELARD, C., SONJAYA, H., HELAL, A. N. AND BRITTON-DAVIDIAN, J. 1986. Robertsonian house mouse populations in Tunisia: a karyological and biochemical study. Genetica, 68, 151-156.

SAID, K. AND BRITTON-DAVIDIAN, J. 1991. Genetic differentiation and habitat partition of Robertsonian house mouse populations (Mus musculus domesticus) of Tunisia. J. Evol. Biol., 4, 409-427.

SITES, J. W., Jr. AND MORITZ, C. 1987. Chromosomal evolution and speciation revisited. Syst. Zool, 36, 153-174.

SPIRITO, F. 1992. The exact values of the probability of fixation of underdominant chromosomal rearrangements. Theor. Pop. Biol., 41, 111-120.

SPIRITO, F, ROSSI, C. AND RIZZONI, M. 1991. Populational interactions among underdominant chromosomal rearrangements help them persist in small demes. J. Evol. Biol., 4, 501-512.

VIROUX, M. C. AND BAUCHAU, v. 1992. Segregation and fertility in Mus musculus domesticus (wild mice) heterozygous for the $\mathrm{Rb}(4.12)$ translocation. Hered., 68, 131-134.

WALLACE, B. M. N. AND SEARLE, J. 1990. Synaptonemal complex studies of the common shrew (Sorex araneus). Comparison of Robertsonian heterozygotes and homozygotes by light microscopy. Hered., 65, 359-367.

WAllace, B. M. N., SEARLE, J. B. AND EVERETT, C. A. 1992. Male meiosis and gametogenesis in wild house mice (Mus musculus domesticus) from a chromosomal hybrid zone; a comparison between 'simple' Robertsonian heterozygotes and homozygotes. Cytogenet. Cell Genet., 61, 211-220.

WHITE, M. J. D. 1968. Models of speciation. Science, 159, 1065-1070.

WINKING, H., DULIC, B. AND BULFIED, G. 1988. Robertsonian karyotype variation in the European house mouse, Mus musculus. Survey of present knowledge and new observations. Z. Säugertierkunde, 53, 148-161.

WINKING, H. AND GROPP, A. 1976. Meiotic non-disjunction of metacentric heterozygotes in oocytes versus spermatocytes. In: Crosignani, P. G. and Mishell, D. R. (eds) Ovulation in the Human: Proceedings of the Serono Symposium vol. 8, Academic Press, pp. 47-56. 